DANUTA JANCZEWSKA

Społeczna Akademia Nauk w Łodzi, Polska - Social Academy of Science in Lodz, Poland

\title{
Proces zarządzania wiedzą w mikroprzedsiębiorstwie w aspekcie przekształcania w firmę inteligentną
}

\author{
Knowledge Management Process in Micro Enterprise - in View of Creation \\ of Intelligent Enterprise
}

Streszczenie: Problematyka zarządzania wiedzą jest szeroko prezentowana $\mathrm{w}$ literaturze przedmiotu. Rozwój przedsiębiorczości jest obecnie jednym w ważniejszych uwarunkowań w realizacji założeń gospodarki opartej na wiedzy. Zajmuje również znaczącą pozycję w Programie Horyzont 2020. Gospodarka oparta na wiedzy charakteryzuje się dużą aktywnością innowacyjną, rozumianą jako wdrażanie ze znaczną intensywnością nowych produktów, technologii, a także innowacji z zakresu zarządzania. Koncentruje się ona na transferowaniu idei, wyników badań naukowych i umiejętności między jednostkami naukowo-badawczymi a grupami użytkowników. Nowy paradygmat teorii innowacji zakłada również dwukierunkowy przepływ wiedzy, idei czy technologii między przedsiębiorstwem a otoczeniem. Na początku XXI w. wiedza stała się podstawą uzyskania przewagi konkurencyjnej, co spowodowało zwiększenie zainteresowania przedsiębiorstw problematyką zarządzania wiedzą jako zasobem. Niewiele badań dotyczy mikroprzedsiębiorstw, co sprawia, iż znane modele zarządzania wiedzą nie znajdują zastosowania $\mathrm{w}$ objaśnianiu procesu zarządzania wiedzą w tym sektorze. Celem artykułu jest przedstawienie problematyki zarządzania wiedzą w mikroprzedsiębiorstwie oraz uwarunkowań procesu przekształcania w firmy inteligentne. W artykule podjęto próbę modelowego ujęcia procesu wewnątrz badanych firm na podstawie badań własnych mikroprzedsiębiorstw.

\begin{abstract}
Problems of Knowledge Management have a wide position in literature. Development of entrepreneurship is now one of main barriers of realization of Knowledge Based Economy. It has a main position in Horizon 2020 Program in the European Union. KBE is characterized by innovative activity, understood as implementation with much intensity of new products, technologies, and innovative management methods. KBE is concentrated on transferring new ideas, results of science researches and abilities between institutions of science and research and users groups. A new paradigm of innovation presents two-way flow of knowledge, ideas, technologies between enterprise and their environment, too. In the beginning of 21 st century knowledge became the basis to reach the competitive advantages, and now enterprises understand knowledge as a resource. Not so many articles concentrate on micro enterprise and known models of $\mathrm{KM}$ are not useful to explanation of $\mathrm{KM}$ process in micro enterprises sector. The goal of this article is a presentation of main problems of Knowledge Management in a micro enterprise and conditions of process of transformation into intelligent enterprises.
\end{abstract}


Słowa kluczowe: mikroprzedsiębiorstwo; przedsiębiorczość; zarządzanie wiedzą

Key words: entrepreneurship; knowledge management; micro enterprise

Otrzymano: 10 listopada 2015

Received: 10 November 2015

Zaakceptowano: 6 marca 2016

Accepted: 6 March 2016

\section{Sugerowana cytacja/Suggested citation:}

Janczewska, D. (2016). Proces zarządzania wiedzą w mikroprzedsiębiorstwie w aspekcie przekształcania w firmę inteligentną. Przedsiębiorczość - Edukacja, 12, 164-175.

Wstęp

Mikroprzedsiębiorstwa znajdują się obecnie w obszarze zainteresowania wielu badaczy. Zgodnie z definicją Komisji Europejskiej, mikroprzedsiębiorstwa charakteryzują dwa parametry: zatrudnienie mniej niż 10 pracowników oraz obrót roczny jako kwota przyjętych pieniędzy w danym okresie lub bilans (zestawienie aktywów i pasywów firmy) poniżej $2 \mathrm{mln}$ euro (Mikroprzedsiębiorstwa..., 2015). W artykule przedstawiono wyniki badań własnych prowadzonych w latach 2012-2015 wśród menedżerów zatrudnionych w mikroprzedsiębiorstwach zlokalizowanych w województwie łódzkim oraz mazowieckim. Sformułowano następujące hipotezy:

H1: W mikroprzedsiębiorstwie można wskazać czynniki stymulujące przepływ wiedzy oraz kształtujące postawy przedsiębiorcze.

H2: Wiedza jest w mikroprzedsiębiorstwie elementem wspierającym jego rozwój oraz przekształcenie w firmę inteligentną.

Badania prowadzono metodą bezpośrednich wywiadów, ankiet, rozmów z ekspertami oraz analiz dokumentów i raportów. Dobór próby był celowy i obejmował przedsiębiorstwa, których menedżerowie kształcili się na uzupełniających studiach magisterskich. Uzasadnieniem wyboru tematu problemu badawczego jest konieczność identyfikacji procesu zarządzania wiedzą w mikroprzedsiębiorstwie. Ze względu na małą liczebność próby wnioski z badań dotyczą wyłącznie badanych mikroprzedsiębiorstw.

Współczesne koncepcje dotyczące zarządzania wiedzą przypisują jej znacząca rolę w rozwoju przedsiębiorstwa. Znaczenie wiedzy jako zasobu znajduje odniesienie w koncepcjach zasobowych rozwoju wzrostu przedsiębiorstwa (Teece, 1999). Wiedza postrzegana w kategorii zasobu jest ściśle powiązana z procesami przetwarzania danych i informacji. Dane są podstawowymi elementami tworzącymi wiedzę, pozbawionymi jednak znaczenia bez odpowiedniego kontekstu. Dopiero dane wyselekcjonowane, pogrupowane, porównane, połączone i zestawione w odpowiednim kontekście oraz poddane ocenie stają się informacją. Z kolei informacje, którym zostanie nadana odpowiednia struktura umożliwiająca ich wykorzystanie w określonym obszarze działalności, tworzą wiedzę. (Sopińska, 2008: 67-81). Pojęcie „wiedza” nie ma precyzyjnej interpretacji w literaturze ekonomicznej, w przeciwieństwie do pojęcia „technologia” rozumianego jako ogólna wiedza techniczna, dotycząca poszczególnych obszarów techniki. 


\section{Znaczenie wiedzy jako zasobu w mikroprzedsiębiorstwie}

Transfer wiedzy (Knowledge Transfer - KT) jest pomostem pomiędzy tymi, którzy tworzą wiedzę i informacje, a tymi, którzy ich potrzebują ${ }^{1}$. Transfer wiedzy będzie miał różnorodny przebieg w zależności od: rodzaju wiedzy, która jest przekazywana, rodzaju zadań, do wykonywania których dana wiedza jest potrzebna, okoliczności, w jakich dana wiedza ma być wykorzystywana, uczestników procesu transferu wiedzy.

Podstawy gospodarki opartej na wiedzy tworzą trendy: wzrostu znaczenia sfery usług i inwestycji w aktywa niematerialne, upowszechnienia nowych technologii informacyjno-komunikacyjnych (ICT) oraz budowy społeczeństwa informacyjnego, a także nowe wymagania i podejście do wiedzy w uczących się organizacjach (Platonoff, Sysko-Romańczuk, Moszoro, 2004). Zarządzanie wiedzą staje się w tym kontekście bardzo ważnym procesem biznesowym, którego objaśnienie odnaleźć można w teorii ekonomii wiedzy. Stawia ona wiedzę na pozycji atrybutu niezbędnego do realizacji koncepcji nowej gospodarki.

W świetle Programu Horyzont 2020 w centrum zainteresowania Unii Europejskiej znajduje się zarówno kreowanie przedsiębiorczości, jak i zarządzanie wiedzą. Założenia sformułowane $\mathrm{w}$ tym programie stają się w przedsiębiorstwie zasobem niezbędnym, a proces zarządzania wiedzą może przyczynić się do wzrostu potencjału konkurencyjnego mikrofirmy.

Nowym wyzwaniem dla przedsiębiorstw i kierunkiem ich rozwoju w XXI w. staje się otwarcie na współpracę i współtworzenie innowacji na wielu płaszczyznach (Gierszewska, 2011). Powstające systemy monitorowania i zarządzania zasobami wiedzy przyczyniły się do rozwoju organizacji, a zjawiska społeczne, ekonomiczne i organizacyjne wymagały nowej filozofii zarządzania oraz nowego sposobu objaśniania.

Istniejące modele zarządzania wiedzą powstały na podstawie badań przedsiębiorstw dużych. Prekursorzy zarządzania wiedzą przewidywali wzrost znaczenia wiedzy (Drucker 1999: 9-20). Na tej podstawie zdefiniowany został pogląd dotyczący przesunięcia paradygmatu i rewolucji w nauce (Sułkowski, 2004), w którym zauważa się nieciągłość zmian w nauce oraz przechodzenie w sposób gwałtowny od jednego nurtu w zarządzaniu do drugiego. Taka gwałtowna zmiana następuje obecnie przy przechodzeniu od gospodarki przemysłowej do gospodarki wiedzy.

Współczesne rozumienie źródeł wiedzy ulega modyfikacji, gdyż sposób i miejsce powstawiania wiedzy przypisywane były instytucjom sfery nauki, takim jak szkoły wyższe, instytuty i ośrodki badawcze, zaś obecnie rolę tę przyjmują również przedsiębiorstwa. Generują one wiedzę, wykorzystując ją w celu doskonalenia własnych produktów, technologii wytwórczych lub metod zarządzania i organizacji pracy. Powstają też nowe formy organizacyjne, zajmujące się zbieraniem, przetwarzaniem i oferowaniem informacji - są to tzw. domy wiedzy. Wzrasta rola przedsiębiorstw jako źródeł wiedzy, zwłaszcza organizacji inteligentnych. Organizacja ucząca się i kreująca nową wiedzę potwierdza nowe podejście do zarządzania wiedzą i udowadnia dwukierunkowy przepływ wiedzy. Dotychczasowe poglądy na temat wiodącej roli sfery nauki jako kreatora wiedzy i jej źródła dla sfery industrialnej ulegają całkowitej przemianie. Przedsiębiorstwo staje się odbiorcą wiedzy i zarazem jej twórcą. Proces generowania wiedzy wyzwala zdolności twórcze pracowników na różnych szczeblach zarządzania, co z kolei poprawia aktywność całej organizacji w wielu dziedzinach funkcjonowania.

${ }^{1}$ Objaśnienie pojęcia „transfer wiedzy” zostało zawarte w publikacji MEECE Knowledge Transfer Strategy 2009, http://www.meece.eu/kt/docs/MEECE_KT\%20Strategy.pdf. 
Wiedza jako zasób mikroprzedsiębiorstwa

Zarządzanie wiedzą występuje jako nowy kierunek i stanowi narzędzie do usprawniania procesów w przedsiębiorstwie. Proces zarządzania wiedzą polegać będzie na ciągłym przekształcaniu wiedzy ukrytej w jawną oraz na upowszechnianiu tej wiedzy. W tym procesie najważniejszym czynnikiem staje się identyfikacja wartości firmy oraz zdefiniowanie strategii na przyszłość. Istotą procesu jest permanentne poszukiwanie współczesnych metod i rozwiązań, które mogą stymulować wzrost konkurencyjności mikrofirmy na rynku. Należy zatem rozpatrzyć możliwość kształcenia przyszłych mikroprzedsiębiorców w zakresie korzystania z transferu współczesnej wiedzy, zarządzania tą wiedzą, wartościami firmy oraz umiejętności implementacji współczesnych koncepcji i metod zarządzania. Wiedza traktowana jako zasób może być analizowana i oceniana w mikroprzedsiębiorstwie $\mathrm{z}$ wielu punktów widzenia: $\mathrm{z}$ pozycji właściciela, z pozycji zatrudnionych pracowników, jako ocena firm konkurencyjnych, jako ocena firm poszukujących np. podwykonawców, dostawców czy kooperantów. Ocena zasobów wiedzy może być dokonana przez właściciela mikrofirmy, który posiada wiedzę praktyczną, niezbędną do założenia przedsiębiorstwa oraz prowadzenia działalności gospodarczej. Gromadzi on również wiedzę na temat możliwych do realizacji sposobów osiągania sukcesu w branży czy na rynku, na którym mikrofirma prowadzi działalność. Jego wiedza obejmuje również trendy w branży czy elementy konkurencyjności ważne w danym czasie i miejscu.

Oceniając indywidualny kapitał intelektualny właściciela, można wyróżnić następujące kategorie:

- wiedzę kompleksową i specjalistyczną,

- doświadczenie w prowadzeniu biznesu,

- cechy, zdolności i umiejętności,

- wykształcenie przedsiębiorcy,

- chłonność na nową wiedzę lub wiedzochłonność ${ }^{2}$,

- świadomość roli wiedzy w mikroprzedsiębiorstwie,

- umiejętność zarządzania kapitałem intelektualnym w przedsiębiorstwie.

A. Wziątek-Kubiak definiuje zasoby wiedzy w przedsiębiorstwie jako unikalne i powiązane $\mathrm{z}$ miejscem akumulowania wiedzy, trudne do transferowania do otoczenia przedsiębiorstwa (Wziątek-Kubiak, 2009). Pozostają one zatem jej indywidualnym zasobem, który nie podlega transferowaniu poza obszar organizacji. Można więc przechwycić tylko część zasobów wiedzy innowatorów. Badania prowadzone przez M. Juchniewicz i B. Grzybowską wskazały na kluczowe umiejętności i znaczenie zasobów wiedzy niezbędnej w prowadzeniu własnego przedsiębiorstwa (Juchniewicz, Grzybowska, 2010). W opinii badanych najczęściej poszukiwaną informacją jest ta, która umożliwia kontynuowanie dotychczasowej działalności oraz wskazuje sposoby zarabiania pieniędzy.

\section{Proces zarządzania wiedzą w mikroprzedsiębiorstwie}

Badania nad sektorem mikroprzedsiębiorstw w Polsce prowadzone przez PARP w roku 2013 zawierają prognozy do roku 2020 oraz określają kierunki dynamizujące rozwój sektora mikrobiznesu (Nieć, 2013). Za szczególnie istotne dla sektora mikrofirm autorzy raportu PARP uznali następujące prognozy:

${ }^{2}$ Szerzej na temat wiedzochłonności organizacji: Białoń, L., Janczewska, D. (2007). Wiedzochłonność procesów innowacyjnych. Cz. I. Postępy Techniki Przetwórstwa Spożywczego, 2, t. 17/31, 93-97. 
- Szczególnie dynamiczny będzie rozwój biznesów opartych na zarządzaniu wielkimi zbiorami danych (big data $)^{3}$.

- Nastąpi spadek liczebności firm średniej wielkości do roku 2020 przy jednoczesnym intensywnym rozwoju mikroprzedsiębiorstw.

- Bariery rozwojowe grupy firm mikro będą ograniczane przez rozwój technologii i techniki, wykorzystanie outsourcingu, wirtualizację działalności.

- Zmieni się struktura sektora MŚP w związku ze zmniejszaniem się liczby firm średnich, które albo będą rozwijać się i stawać firmami dużymi, albo będą przekształcać się w mniejsze organizacje.

- Efektem zmian w strukturze zarządzania będzie spadek znaczenia menedżerów średniego szczebla związany z rozwojem technologii IT.

- Zmniejszy się zapotrzebowanie na infrastrukturę fizyczną (w rozumieniu miejsc prowadzenia działalności, w tym działalności handlowej i usług biurowych).

- Konsument stanie się głównym źródłem innowacji.

Wiedza w mikroprzedsiębiorstwie jest zazwyczaj wiedzą wynikającą z doświadczenia właściciela oraz jego pracowników. Przedsiębiorstwa mikro nie otrzymują ofert pomocy w tym zakresie ze strony sfery nauki oraz instytucji publicznych i administracji (Barańska-Fischer, 2010). M. Kozioł przedstawia pogląd, iż jedną z ważniejszych barier wewnętrznych rozwoju małego przedsiębiorstwa jest bariera edukacyjna (Kozioł, 2013), co potwierdzają badania własne autorki. Kozioł wymienia następujące czynniki utrudniające rozwój firmy MŚP:

- słaba kultura przedsiębiorczości,

- słaba znajomość nowoczesnych metod zarządzania,

- ograniczony dostęp do informacji gospodarczej,

- brak umiejętności pozyskiwania, gromadzenia i wykorzystywania informacji z otoczenia,

- niski stopień wykorzystania Internetu i innych narzędzi IT,

- luki w potencjale kwalifikacyjnym spowodowane niskimi kwalifikacjami pracowników,

- wysoka fluktuacja pracowników, zwłaszcza specjalistów,

- niska zdolność i skłonność do uczenia się.

A. Wilmańska wskazuje na brak systemu kształcenia w zakresie small businessu i inne (Wilmańska, 2010). Proces zarządzania wiedzą w mikroprzedsiębiorstwie w samej istocie jest znacznie bardziej uproszczony niż modele oparte na dużych organizacjach. Pojawia się potrzeba zatrudniania w mikroprzedsiębiorstwach pracowników mających wiedzę oraz umiejętność stosowania tejże wiedzy w złożonych warunkach funkcjonowania. Wyodrębniono cechy menedżera odpowiadające potrzebom współczesnej gospodarki opartej na wiedzy, co wiąże się ze specyfiką danego przedsiębiorstwa, jego strukturą organizacyjną oraz przyjętym modelem funkcjonowania organizacyjnego (Miodek, Speer, 2014).

Brak jest definicji kapitału intelektualnego mikroorganizacji w sensie jego niematerialnego charakteru i wspólnego poglądu na ten temat (Czechowska-Świtaj, 2005). Definicje oparte na doświadczeniach dużych organizacji wykluczają przypisywanie tejże cechy mikrofirmom.

Wilmańska (Wilmańska, 2010) dodatkowo podkreśla występowanie luki w potencjale rozwoju pracowników spowodowanej niskimi kwalifikacjami, wysoką fluktuacją pracowników, zwłaszcza specjalistów, niską zdolnością i skłonnością do uczenia się, brakiem systemu kształcenia w zakresie small businessu i wieloma innymi. W przypadku firm mikro wyraźnie

\footnotetext{
${ }^{3}$ Prahalad i Krishnan uważają za najważniejszą umiejętność zrozumienia nagromadzonych informacji i przetwarzania ich w celu wsparcia procesów zarządzania - szerzej na ten temat w książce: Prahalad, C.K., Krishnan, M.S. (2010). Nowa era innowacji. Warszawa: PWN, 67.
} 
zaznacza się tendencja do braku oczekiwań względem jednostek sfery nauki, powiązania z regionem oraz preferowaniem rozwiązań doraźnych realizowanych samodzielnie i dostępnych cenowo (Santarek, 2008). Z kolei autorka niniejszego artykułu wskazuje na występowanie przedsiębiorstw opartych na wiedzy w sektorze mikroprzedsiębiorstw (Janczewska, 2013), które charakteryzują się następującymi cechami: planują swój przyszły rozwój, przewidują wydatki związane $\mathrm{z}$ nabyciem lub tworzeniem nowej wiedzy, są w stanie ocenić swój potencjał innowacyjny oraz są przygotowane na rosnącą konkurencję ze strony innych przedsiębiorstw opartych na wiedzy.

\section{Kreowanie procesu zarządzania wiedzą - interpretacja modelu liniowego oraz modelu GEM}

Wśród wielu znanych modeli zarządzania wiedzą nie wszystkie mogą posłużyć do interpretacji procesu zarządzania wiedzą $\mathrm{w}$ mikroprzedsiębiorstwie ${ }^{4}$. W tym podrozdziale porównano model liniowy oparty na podejściu procesowym z modelem Globalnego Monitora Przedsiębiorczości (GEM). W modelu liniowym, przedstawionym na rycinie 1, widoczne są relacje pomiędzy poszukiwaniem wiedzy a jej implementacją w mikrofirmie. Model ten w sposób uproszczony opisuje interakcje pomiędzy poszczególnymi etapami pozyskiwania i wykorzystywania wiedzy (Gierszewska, 2011). Nie uwzględnia on w sposób kompleksowy wpływu otoczenia oraz nie rozróżnia poszczególnych kategorii wiedzy. Na podstawie modelu liniowego trudno jest określić, w jaki sposób zdobywanie, gromadzenie i przetwarzanie wiedzy może być wykorzystane w mikroprzedsiębiorstwie. Wymagane jest tworzenie dodatkowych opisów oraz identyfikacji struktur oraz zasobów wiedzy.

Ryc. 1. Model liniowy zarządzania wiedzą

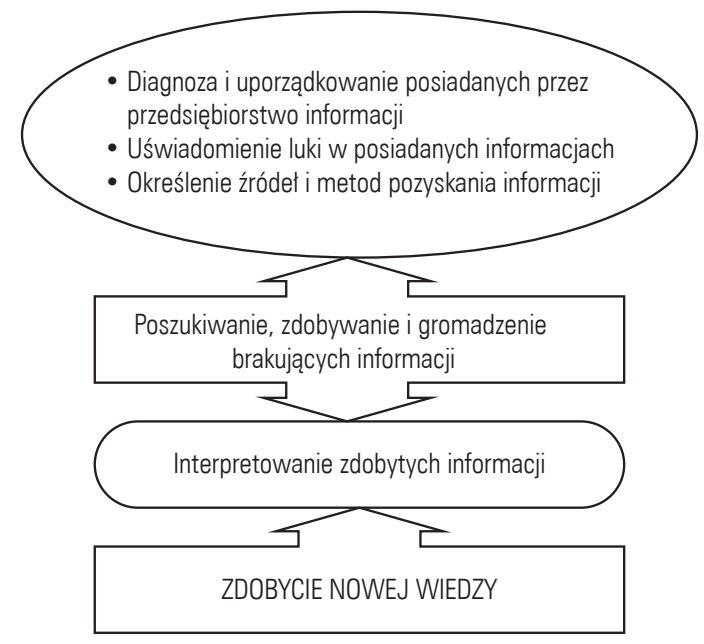

Źródło: opracowanie własne na podstawie: Gierszewska (2011)

\footnotetext{
${ }^{4}$ Między innymi autorka nie odwołuje się do klasycznego modelu Nonaki i Takeuchi ze względu na odmienny charakter zarządzania wiedzą w mikroprzedsiębiorstwie, natomiast dyskusja nad ich modelem spiralnym przekracza ramy niniejszego artykułu. W tym miejscu składam podziękowania Recenzentowi za istotną uwagę w tym zakresie.
} 


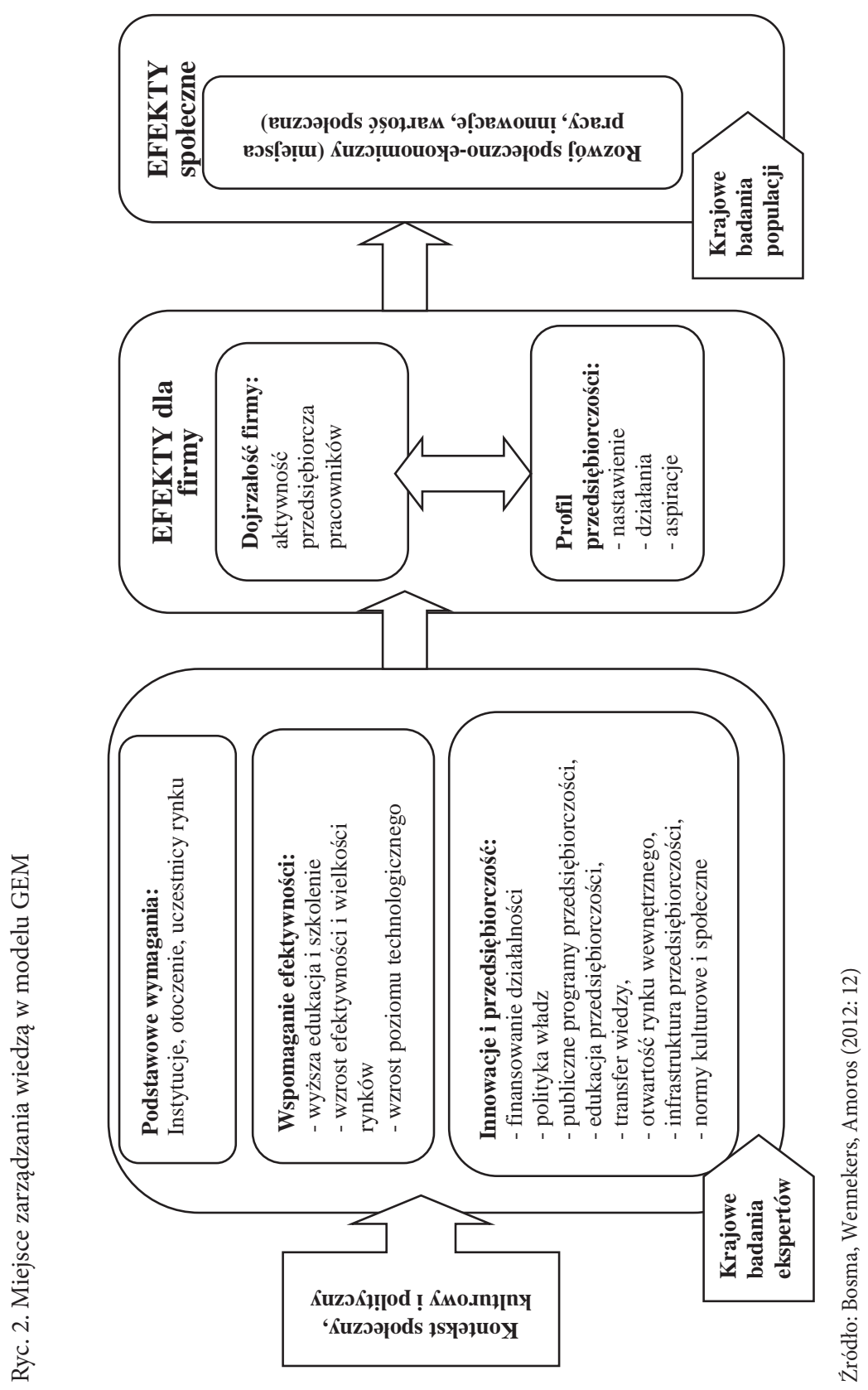


Koncepcja GEM uważana jest za bardziej skomplikowany model opisujący udział wiedzy w kreowaniu pozycji danego kraju, który stara się budować GOW. Globalny Monitor Przedsiębiorczości to rozwój w kilku płaszczyznach: w płaszczyźnie geograficznej, politycznej, naukowej, praktycznej i intelektualnej, zakładający istnienie relacji między kontekstami: kulturowym, politycznym, społecznym i ekonomicznym, warunkami ramowymi, aktywnością przedsiębiorczą społeczeństwa i firm, a także rozwojem gospodarczym i wzrostem zatrudnienia jako wynikiem tych procesów. Globalny Monitor Przedsiębiorczości jest instrumentem służącym do badania i określania zmian w rozwoju poszczególnych krajów i gospodarek, obejmuje swoim zasięgiem ponad 2/3 ludności świata oraz ponad 90\% globalnego produktu brutto (Tarnawa, Zadura, 2014). Model GEM pokazano na rycinie 2.

Zaletą modelu GEM jest jego wielowymiarowość oraz możliwość stosowania do analiz porównawczych pomiędzy poszczególnymi gospodarkami. Wydaje się, że z punktu widzenia sektora mikrofirm model ten wymaga dużego zaangażowania oraz wielu badań w celu sporządzenia dokładnego opisu modelu zarządzania wiedzą wujęciu GEM. Koncepcja GEM może być uwzględniona podczas kontynuowania badań własnych na większej próbie mikroprzedsiębiorstw.

\section{Prezentacja badań własnych nad zarządzaniem wiedzą w mikroprzedsiębiorstwach}

W badaniach własnych autorka poszukiwała oceny zasobów wiedzy oraz zarządzania nimi z punktu widzenia menedżerów zatrudnionych w mikrofirmach, a zatem według oceny pracowników korzystających z zasobów wiedzy lub tworzących tę wiedzę. Etap obecny, realizowany w latach 2012-2015, dotyczył zebrania opinii menedżerów na temat zarządzania wiedzą oraz wskazania cech organizacji jako firmy inteligentnej. Sformułowano następujące pytania pomocnicze: Czy można wskazać elementy zarządzania wiedzą w przedsiębiorstwie? Czy kategorie tej wiedzy pozwalają na określenie przedsiębiorstwa jako organizacji inteligentnej?

Ryc. 3. Struktura badanej grupy przedsiębiorstw z województwa kujawsko-pomorskiego

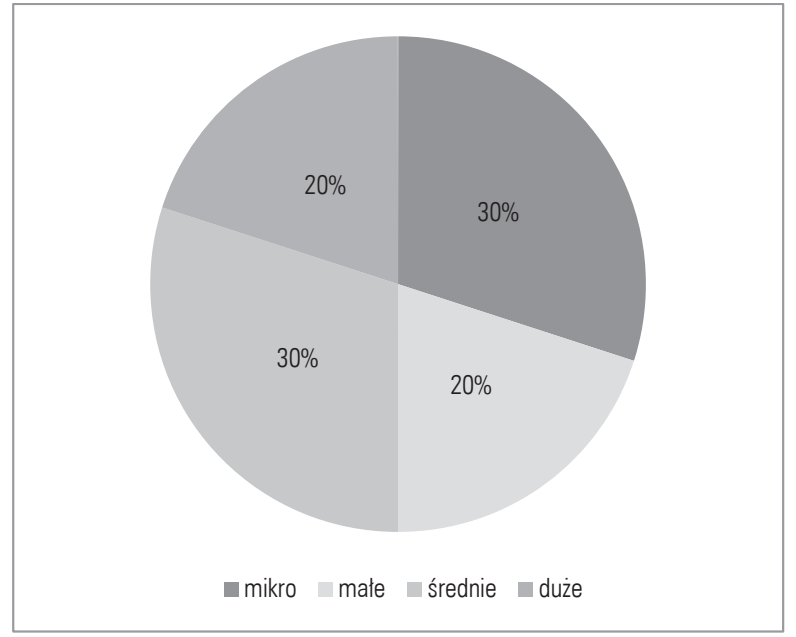

Źródło: opracowanie własne 
Autorka prowadziła badania pilotażowe na obecnym etapie metodą swobodnych wypowiedzi, wywiadów i konsultacji z menedżerami średniego oraz wyższego szczebla. Wypowiedzi menedżerów zbierano drogą internetową, wykorzystując platformę e-learningową Społecznej Akademii Nauk w Łodzi. Prezentowane w niniejszym artykule wyniki dotyczą badań menedżerów z województwa łódzkiego oraz mazowieckiego. W badaniu uczestniczyło 21 osób. Struktura badanych firm została przedstawiona na rycinie 3.

W wypowiedziach dotyczących zarządzania wiedzą w grupie mikroprzedsiębiorstw określano jako istotne następujące elementy:

- wiedza w mikrofirmach jest wyłącznie związana z techniką i technologią właściwą dla danej branży czy gałęzi przemysłu, w której funkcjonuje przedsiębiorstwo - 80\% wskazań;

- źródła wiedzy specjalistycznej: nabyta w czasie studiów lub szkoleń (50\%), nabyta przez doświadczenie (40\%), pozyskana w Internecie (10\%).

Jako źródła wiedzy badani wskazywali doświadczenie, Internet, narady, szkolenia, targi, wystawy, studia, spotkania $\mathrm{z}$ klientami. Największe znaczenie miały według badanych studia jako źródło wiedzy (ryc. 4). Pozyskiwanie wiedzy na targach i wystawach zajmuje ostatnią pozycję jako źródło wiedzy. Może to wynikać z braku środków na pokrycie kosztów uczestnictwa w tych wydarzeniach.

Ryc. 4. Źródła wiedzy w mikroprzedsiębiorstwie - wyniki badań

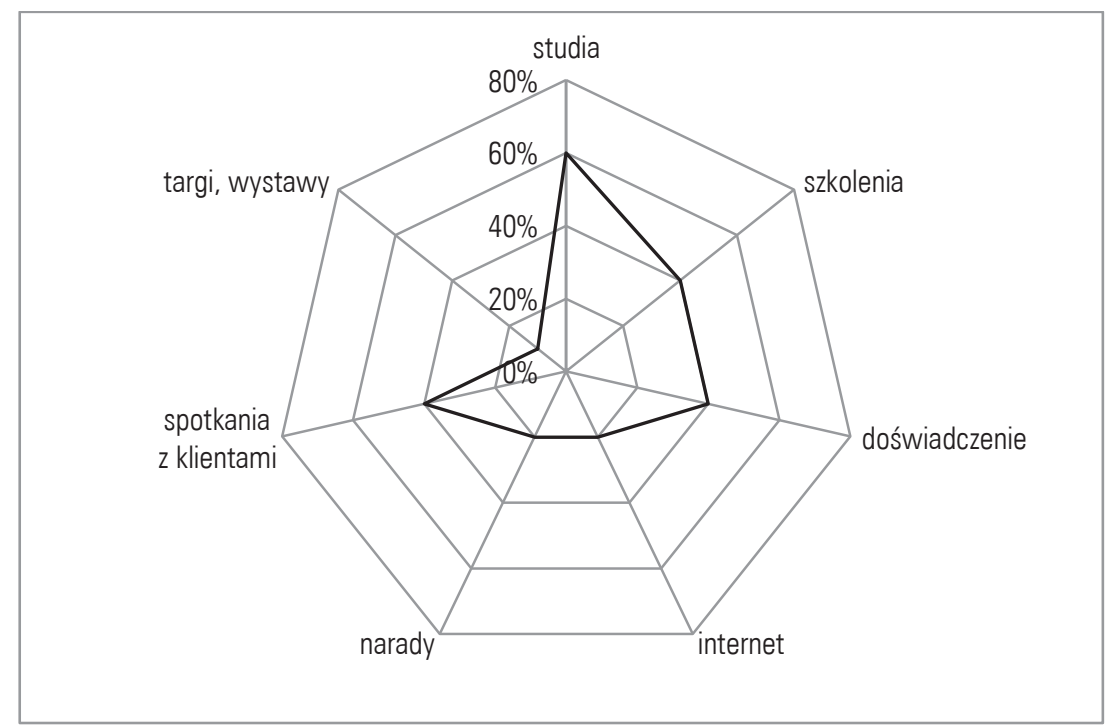

Źródło: opracowanie własne

Według opinii badanych w mikroprzedsiębiorstwie występują określone kategorie wiedzy, które mogą świadczyć o tym, że jest ono zainteresowane powiększaniem zasobów wiedzy oraz przekształceniem się w firmę inteligentną; przy czym wskazywano następujące rodzaje wiedzy:

- wiedza z zakresu ekonomii i zarządzania (40\%): w zakresie niezbędnym do wykonywania obowiązków (70\%), wiedza o źródłach finansowania (30\%), wiedza o przepisach prawnych i podatkowych $(60 \%)$;

- wiedza z zakresu planowania i prognozowania rozwoju przedsiębiorstwa (80\%);

- wiedza z zakresu marketingu w zakresie informacji o klientach i ich potrzebach (60\%); 
- wiedza o źródłach informacji dostępności szkoleń i kursów oraz edukacji pracowników w zakresie studiów wyższych oraz podyplomowych (40\%);

- wiedza z zakresu informatyki i technik IT, stosowana do komunikacji z otoczeniem oraz komunikacji wewnątrz firmy (80\%);

- wiedza logistyczna jako specyficzny i unikalny obszar zastosowania wiedzy logistycznej do wspomagania zarządzania procesami w przedsiębiorstwie.

Na podstawie wywiadów $\mathrm{z}$ badanymi menedżerami sformułowano własny model zarządzania wiedzą w mikroprzedsiębiorstwie oparty ma modelu zasobowym (ryc. 5).

Ryc. 5. Zasoby wiedzy w procesie zarządzania wiedzą w mikroprzedsiębiorstwie

\begin{tabular}{|l|}
\hline Zasoby wiedzy: \\
- kapitał intelektualny \\
umiejętność badań otoczenia \\
- znajomość trendów \\
w branży
\end{tabular}

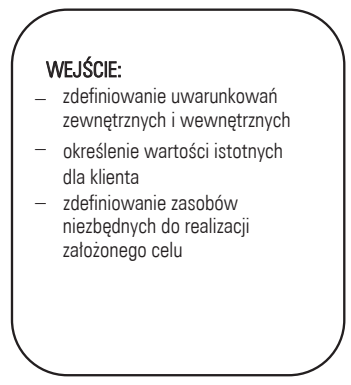

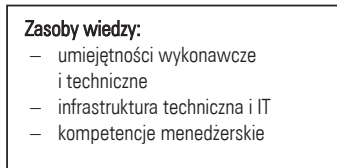

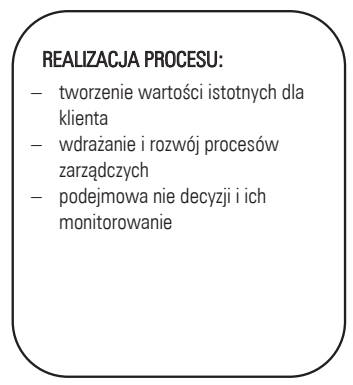

Zasoby wiedzy:

- umiejętność monitorowania efektów oraz definiowania i wprowadzania działań korygujących

Źródło: opracowanie własne

Uzyskane wyniki badań pozwoliły na identyfikację poszczególnych elementów modelu: wejścia, realizacji oraz wyjścia. Kolejnym krokiem w badaniach może stać się badanie efektywności procesu oraz identyfikacja czynników stymulujących proces budowy systemu wiedzy w mikroprzedsiębiorstwie.

\section{Podsumowanie}

W artykule przedstawiono badania literaturowe nad procesem zarządzania wiedzą w mikroprzedsiębiorstwie. Porównano dwa modele zarządzania wiedzą pod względem ich przydatności do interpretowania procesu zarządzania wiedzą w mikroprzedsiębiorstwie. W wyniku badań wybranych mikroprzedsiębiorstw potwierdzone zostały przyjęte hipotezy. Badani menedżerowie odpowiedzieli twierdząco na pytanie dotyczące możliwości określenia przedsiębiorstwa jako firmy inteligentnej. Wypowiedzi menedżerów na temat mniej ważnych (ich zdaniem) działań dotyczyły następujących elementów zarządzania wiedzą: ciągłe uzupełnianie i nabywanie nowej wiedzy oraz nowych umiejętności i wiadomości, tworzenie własnego zaplecza badawczo-rozwojowego, współpracy ze sferą nauki, wprowadzanie nowych projektów i usprawnień organizacyjnych, projektowanie nowych technologii, korzystanie z opracowań ze sfery $\mathrm{B}+\mathrm{R}$. W celu poszukiwania modelu dokładniej 
opisującego proces zarządzania wiedzą w mikroprzedsiębiorstwie celowe wydaje się prowadzenie dalszych badań na większej grupie docelowej.

Literatura

References

Barańska-Fischer, M. (2012). Rola organów administracji publicznej w kreowaniu środowiska proinnowacyjnego w regionie łódzkim. W: K. Szymańska, A. Walecka (red.), Wybrane aspekty zarzadzania nowoczesną organizacją. Studia ekonomiczne regionu łódzkiego, VIII, Łódź: Wyd. PTE Oddz. w Łodzi.

Białoń, L., Janczewska, D. (2007). Wiedzochłonność procesów innowacyjnych. Cz. I. Postępy Techniki Przetwórstwa Spożywczego, 2, 17/31, 93-97.

Bosma N., Wennekers S., Amoros J.E. (2012). Global Entrepreneurship Monitor 2011 Extended Report: Entrepreneurs and Entrepreneurial Employees Across the Globe, London: Global Entrepreneurship Research Association.

Czechowska-Świtaj, T. (2005). Zarządzanie kapitałem intelektualnym w organizacji, Warszawa: Oficyna Wydawnicza Wyższej Szkoły Menedżerskiej.

Cyrek, M. (2006). Wybrane koncepcje pomiaru gospodarki opartej na wiedzy. Zeszyty Naukowe Uniwersytetu Rzeszowskiego, 10, 208-224.

Drucker, P. (1999). Społeczeństwo prokapitalistyczne. Warszawa: Wydawnictwo Naukowe PWN.

EUROPA, EU law and publications, EUR-Lex - n26026. (2015, 1 grudnia). Pozyskano z: http://eur-lex. europa.eu/legal-content/PL/TXT/?uri=URISERV:n26026

Gierszewska, G. (2011). Zarządzanie wiedzq w przedsiębiorstwie. Warszawa: Oficyna Wydawnicza Politechniki Warszawskiej.

Janczewska, D. (2013). Logistyczno-marketingowe uwarunkowania transferu wiedzy w sektorze mikroprzedsiębiorstw. Prace Komisji Geografii Przemysłu Polskiego Towarzystwa Geograficznego, 21 , 225-238.

Juchniewicz, M., Grzybowska, B. (2010). Innowacyjność mikroprzedsiębiorstw w Polsce. Warszawa: PARP.

Kozioł, M. (2013). Wykorzystanie e-learningu w procesie szkolenia pracowników małych i średnich przedsiębiorstw, Zeszyty Naukowe Małopolskiej Wyższej Szkoły Ekonomicznej w Tarnowie, t. 22, $1,45-57$.

Kwiatkowski, M., Symela, K. (2001). Standardy kwalifikacji zawodowych. Teoria, metodologia, projekty. Warszawa: Instytut Badań Edukacyjnych.

MEECE Knowledge Transfer Strategy 2009 (2015, 1 grudnia). Pozyskano z: http://www.meece.eu/kt/ docs/MEECE_KT\%20Strategy.pdf

Mikroprzedsiębiorstwa oraz małe $i$ średnie przedsiębiorstwa - definicja i zakres (2015, 1 grudnia). Pozyskano z: http://eur-lex.europa.eu/legal-content/PL/TXT/?uri=URISERV:n26026

Miodek, P., Speer Ł. (2014). Inżynier globalny - z perspektywy prawa i zarządzania. Przedsiębiorstwo Przyszłości, 1(18), 50-51.

Nieć, M. (2013). Sytuacja mikroprzedsiębiorstw w Polsce w latach 2011-2012. W: A. Tarnawa, P. Zadura-Lichota (red.), Raport o stanie sektora małych $i$ średnich przedsiębiorstw $w$ Polsce $w$ latach 2011-2012. Warszawa: PARP.

Platonoff, A.L., Sysko-Romańczuk, S., Moszoro, B. (2004). Innowacyjność polskich firm w gospodarce opartej na wiedzy, Ekonomika i Organizacja Przedsiębiorstw, 1, 87-92.

Prahalad, C.K., Krishnan, M.S. (2010). Nowa era innowacji. Warszawa: PWN.

Santarek, K., (red.) (2008). Transfer technologii z uczelni do biznesu. Tworzenie mechanizmów transferu technologii. Warszawa: PARP.

Sopińska, A., Wachowiak, P. (2006; 2015, 15 marca). Modele zarządzania wiedzą w przedsiębiorstwie. E-mentor, 1(14). Pozyskano z: http://www.e-mentor.edu.pl/czasopismo/spis-tresci/numer/14 
Sułkowski, Ł. (2004). Neopozytywistyczna mitologia w nauce o zarządzaniu. Organizacja i Zarządzanie, $1,3-14$.

Tarnawa, A., Zadura, P. (2014). Raport Global Entrepreneurship Monitor. Polska. Raport z badań 2013, Warszawa: PARP.

Teece, D.J. (1998). Capturing Value from Knowledge Assets: The New Economy, Market for Know-How, and Intangible Assets. California Management Review, 40(3), 55-79.

Wilmańska, A. (red.) (2010). Raport o stanie matych i średnich przedsiębiorstw w Polsce w latach 2008 2009. Warszawa: PARP.

Wziątek-Kubiak, A. (2009). Od awersji do innowacji do upowszechnienia się innowacji wśród polskich przedsiębiorstw. W: E. Adamowicz (red.), Polska transformacja po latach. Warszawa: C.H. Beck.

Danuta Janczewska, dr inż., Społeczna Akademia Nauk w Łodzi, Katedra Marketingu i Logistyki, Wydział Zarządzania. Adiunkt w Katedrze Marketingu i Logistyki. Jej zainteresowania naukowe są związane z problematyką metodami zarządzania i nowoczesnymi technikami w sektorze mikroprzedsiębiorstw. Autorka ponad 90 publikacji krajowych i zagranicznych. Uczestniczyła w konferencjach krajowych i międzynarodowych na temat przedsiębiorczości i zarządzania w sektorze mikroprzedsiębiorstw. Do najważniejszych badań należy udział w projektach: KBN, PW-004/ITE/01/2004 - 2008: „Rozwój metod transformacji wiedzy i transferu technologii - Temat: Modele procesu transformacji wyników badań naukowych do zastosowań praktycznych oraz systemu zarządzania nimi we współpracy z Uniwersytetem Warszawskim, PARP oraz w badaniach FORESIGHT Polska 2020 jako ekspert zewnętrzny w Programie FORESIGHT - Polska 2020 - w ramach programu UE 2007-2008. Od 2004 r. prowadzi badania własne metod zarządzania w mikroprzedsiębiorstwach.

Danuta Janczewska, Dr. Eng, senior lecturer in Management Faculty in the Social Academy of Science in Lodz, Department of Logistics and Marketing. Research interest include management in micro enterprises, the modern methods of management in micro enterprises. Author of over 90 articles and papers in domestic and foreign journals and conferences. The main research: State Committee for Scientific Research, PW-004/ITE/01/2004-2008. Researches of Models of Knowledge Transformation and Transfer of Technology, and Research of FORESIGHT Poland 2020. Conducts own research of management of micro enterprises. Research in SMEs realized since 2004.

\section{Adres/Address:}

Społeczna Akademia Nauk w Łodzi

ul. Sienkiewicza 9

90-113 Łódź, Polska

e-mail: djanczewska@spoleczna.pl 